\title{
9: 21132144-21130631
}

National Cancer Institute

\section{Source}

National Cancer Institute. 9: 21132144-21130631. NCI Thesaurus. Code C42514.

Physical location of IFNW1_Gene 